medRxiv preprint doi: https://doi.org/10.1101/2021.06.12.21258774; this version posted June 14, 2021. The copyright holder for this preprint (which was not certified by peer review) is the author/funder, who has granted medRxiv a license to display the preprint in perpetuity.

It is made available under a CC-BY-NC-ND 4.0 International license .

\title{
Impact of long-term care facility size on preparedness and adherence to infection prevention and control guidance for the mitigation of COVID-19
}

\author{
Adherence to COVID-19 guidance
}

\section{Patrick Alexander Wachholz*}

Institution: Clinical Research Master's degree Program, Botucatu Medical School, Universidade Estadual Paulista (UNESP), Botucatu, São Paulo, SP, Brazil.

Email: patrick.wachholz@unesp.br ORCID: https://orcid.org/0000-0002-4474-009X

\section{Ruth Caldeira de Melo}

Institution: School of Arts, Sciences and Humanities, Universidade de São Paulo (USP), São Paulo, SP, Brazil

Email: ruth.melo@usp.brＯRCID: http://orcid.org/0000-0002-9713-8617

\author{
Alessandro Ferrari Jacinto \\ Institution: Division of Geriatrics and Gerontology, Escola Paulista de Medicina, \\ Universidade Federal de São Paulo (UNIFESP), São Paulo, SP, Brazil \\ Email: alessandrojacinto@uol.com.brＯRCID: https://orcid.org/0000-0002-1977- \\ 5880
}

\section{Paulo Jose Fortes Villas Boas}

Institution: Internal Medicine Department, Botucatu Medical School, Universidade

Estadual Paulista (UNESP), Botucatu, São Paulo, SP, Brazil.

E-mail: paulo.boas@unesp.brＯRCID: https://orcid.org/0000-0001-9876-3222

* Corresponding author:

Botucatu Medical School, Universidade Estadual Paulista (UNESP)

Av. Prof. Mário Rubens Guimarães Montenegro, s/n - UNESP - CEP 18618-687

Botucatu, São Paulo, SP, Brazil

+55(14) 3322 5458; Pabx: (14) 3880-1001

Twitter handle: @DrPatrickLTC

Authors' contributions: Study conception and design: PAW, RCM, PJFVB; Acquisition of data: PAW, RCM, AFJ, PJFVB; Analysis and interpretation of data: PAW, RCM; Drafting of the manuscript: PAW, RCM, AFJ, PJFVB; Critical revision: PAW, RCM, AFJ, PJFVB. 
medRxiv preprint doi: https://doi.org/10.1101/2021.06.12.21258774; this version posted June 14, 2021. The copyright holder for this preprint (which was not certified by peer review) is the author/funder, who has granted medRxiv a license to display the preprint in perpetuity.

It is made available under a CC-BY-NC-ND 4.0 International license .

\section{Abstract}

Aim: To evaluate the preparedness and adherence of Brazilian long-term care facilities (LTCFs) to the World Health Organization (WHO) infection prevention and control (IPC) guidance and examine the association of LTCF size with adherence to recommendations.

Methods: We conducted a cross-sectional study of LTCF managers for 12 consecutive weeks from May 5, 2020. We developed and pre-tested a 46-item questionnaire based on WHO IPC guidance that included multiple-choice and dichotomous questions as well as an open-ended question on the main difficulties encountered by the facility in tackling the pandemic. Using a global adherence score based on the adoption of 20 recommendations, we classified preparedness as (1) excellent for LTCFs following $\geq 14$ recommendations, (2) good for those following 10-13 recommendations, and (3) poor for those following $<10$ recommendations. LTCF size was established as small, medium, and large according to a 2-step cluster analysis of the number of residents as a continuous variable. We used descriptive statistics and chi-square tests at a $5 \%$ significance level.

Results: Of 362 facilities included in the study, 308 (85.1\%) adhered to 14 or more recommendations; 3 were classified as poorly adherent. Regarding LTCF size, we found a lower adherence to screening visitors for COVID-19 signs and symptoms ( $p=0.037)$ and to isolating patients until they have 2 negative laboratory tests $(p=0.032)$ in larger facilities than in medium and small facilities.

Conclusions: Preparedness for mitigating COVID-19 in Brazilian LTCFs was considered excellent for most of the proposed recommendations, regardless of LTCF size. Difficulties and problems with infrastructure and/or resident care were much less commonly reported than those related to maintenance of a sufficient stock of materials, workforce management, and financial distress.

Keywords: aged; COVID-19; emergency preparedness; guideline adherence; long-term care 


\section{INTRODUCTION}

Older people living in long-term care facilities (LTCFs) have been disproportionately affected by the COVID-19 pandemic..$^{1-4}$ Despite considerable variation, mortality rates in LTCFs accounted for more than 70\% of all COVID-19 deaths during the first and second waves in some countries. ${ }^{2,5}$ The pandemic has not only overwhelmed health systems worldwide but also placed a spotlight on the weaknesses (or absence) of national datasets for LTCFs. ${ }^{6}$

Prevalence of COVID-19 in the community is a strong predictor of number of cases and deaths in LTCFs. ${ }^{3,5}$ Mortality rates have been markedly increased among the most frail residents, as well as among those living in more crowded facilities. ${ }^{7}$ Moreover, the probability of having COVID-19 cases seems to be higher in large not-for-profit facilities located in metropolitan counties. ${ }^{3}$ Consistent with these findings, Abrams et al., examining the characteristics of LTCFs with documented COVID-19 cases in the United States, found that the cases were related to facility location (i.e., urban) and size (i.e., more than 50 beds). ${ }^{1}$ Conversely, Gorges et al. showed that high nurse aide and total nursing hours contribute to mitigating COVID-19 infection in LTCFs. ${ }^{3}$ High staffing ratios $^{7}$ and early and robust infection prevention and control (IPC) practices ${ }^{5}$ seem to be associated with fewer COVID-19 cases and deaths among older adults living in LTCFs.

Early on in the pandemic, the World Health Organization (WHO), the Centers for Disease Control and Prevention ( $C D C)$, and regional organizations published 
medRxiv preprint doi: https://doi.org/10.1101/2021.06.12.21258774; this version posted June 14, 2021. The copyright holder for this preprint (which was not certified by peer review) is the author/funder, who has granted medRxiv a license to display the preprint in perpetuity.

It is made available under a CC-BY-NC-ND 4.0 International license .

recommendations and policy actions to mitigate the impact of COVID-19 on people who rely on the long-term care sector. ${ }^{8-11}$ To the best of our knowledge, however, COVID-19 preparedness in LTCFs and adherence to recommendations published by international organizations have not been sufficiently investigated.

In a study conducted in the United States with a small sample of LTCFs, the most commonly used IPC guidance was CDC recommendations (88\%), followed by state or local health department documents (84\%) and WHO guidance (48\%). ${ }^{12}$ More than half of LTCF managers (54\%) had separate COVID-19 plans, almost all (96\%) had policies for screening visitors, and most of them (68\%) indicated they had a local referral hospital accepting their patients under investigation for COVID-19. Nearly $83 \%$ expected significant staff shortages, while $66 \%$ reported access to COVID-19 testing. ${ }^{12}$

Implementation of evidence into clinical practice is neither easy nor fast. Barriers and facilitators need to be addressed promptly and correctly, particularly at the organizational level. ${ }^{13-15}$ It is not clear whether LTCF size may be a barrier to implementing strategies to reduce the spread of COVID-19. In large LTCFs, for example, the greater the number of residents, staff, and visitors, the greater the need for staff training and rotation schedules for potential absenteeism, the larger the number of demands for staff turnover/retention, and the higher the risk of supply shortage. ${ }^{16,17}$

This study aimed to evaluate the preparedness and adherence of Brazilian LTCF managers to WHO IPC guidance and examine the association of LTCF size with adherence to recommendations for COVID-19 mitigation. 


\section{METHODS}

Ethical approval was given by the institutional review board of the Botucatu Medical School, São Paulo State University (Unesp) for this cross-sectional study (CAAE 30577520.0.0000.0008, protocol no. 4.012.489), and all participants provided online informed consent. The datasets supporting the findings of this study are available in Wachholz, Patrick; Melo, Ruth Caldeira; Jacinto, Alessandro Ferrari; Villas Boas, Paulo José Fortes, 2021, "COVID-19 in Brazilian Long-Term Care Facilities", https://doi.org/10.7910/DVN/LXBFQG, Harvard Dataverse, V1, https://dataverse.harvard.edu/dataset.xhtml?persistentld=doi:10.7910/DVN/LXBFQG. For the purposes of this study, LTCF was defined as a facility that provides long-term care and/or rehabilitative, restorative, and end-of-life care to residents in need of assistance with activities of daily living, including a variety of services (social, medical, and personal care) to people who are unable to live independently.

\section{Design and participants}

We conducted this cross-sectional study exclusively through electronic platforms using Google Forms for 12 consecutive weeks from May 5, 2020. Managers of Brazilian LTCFs for older people were the population of interest. We obtained their contact information through listings on domains available on the internet and by active search with health secretariats, epidemiological surveillance agencies, stakeholders, the Brazilian Unified Social Care System, and LTCF support groups, including websites and 
medRxiv preprint doi: https://doi.org/10.1101/2021.06.12.21258774; this version posted June 14, 2021. The copyright holder for this preprint (which was not certified by peer review) is the author/funder, who has granted medRxiv a license to display the preprint in perpetuity.

It is made available under a CC-BY-NC-ND 4.0 International license .

social media groups. We did not apply restrictions regarding the size, location, or type of facility.

\section{Procedures and measurements}

We developed a 46-item questionnaire based on WHO IPC guidance for LTCFs in the context of COVID-19 published on March 21, 2020, and tested it in a pilot study (Doc S1). ${ }^{18}$ The questionnaire is divided into 9 sections: prevention, physical distancing in the facility, rules for visitors, prospective surveillance for COVID-19 among residents, prospective surveillance among employees, source control, restriction of movement and transport, availability of structure for isolation and provision of personal protective equipment (PPE) and cleaning supplies, and technical support to tackle the pandemic. Of the 46 items, 20 are not part of WHO IPC guidance; however, after consensus among the authors, they were considered both pertinent and essential for understanding the strategies for tackling the pandemic in LTCFs and thereby retained in the questionnaire.

The questionnaire includes multiple-choice and dichotomous questions as well as an open-ended question on the main difficulties encountered by the facility in tackling the pandemic. We created a global score for adherence to WHO IPC guidance based on the adoption of 20 recommendations (Doc S2), as extracted from the original IPC questionnaire. For the purposes of this study, we classified preparedness for COVID-19 as (1) excellent for LTCFs following at least 14 of the 20 recommendations ( $\geq 70 \%),(2)$ good for those following 10 to 13 recommendations (50\% to 69\%), and (3) poor for those following less than 10 recommendations ( $\leq 49 \%)$. 
medRxiv preprint doi: https://doi.org/10.1101/2021.06.12.21258774; this version posted June 14, 2021. The copyright holder for this preprint (which was not certified by peer review) is the author/funder, who has granted medRxiv a license to display the preprint in perpetuity.

It is made available under a CC-BY-NC-ND 4.0 International license .

The questionnaire is available as Doc S1. Doc S2 highlights the questions that make up the global adherence score. The estimated time to complete the questionnaire was 30 minutes. Respondents were able to complete the questionnaire more than once, but each LTCF was included only once in the study. That is, where LTCFs had replied more than once, only the most complete and recent questionnaire was included in the analysis.

\section{Statistical analysis}

We analyzed the data in SPSS version 20 . When respondents did not report data for one or more variables, we described them as missing data and informed their proportional representation. As there is no standard classification for LTCF size, for the purposes of this study, we performed a 2-step cluster analysis of the number of residents as a continuous variable using the automatic clustering algorithm in SPSS version 20. Three clusters were then established: small (<18 residents), medium (19-75 residents), and large LTCFs (>76 residents) LTCFs. We used descriptive statistics and chi-square tests at a $5 \%$ significance level.

We analyzed the responses to the open-ended question using thematic content analysis, ${ }^{19}$ divided into 3 steps: pre-analysis, material exploration, and treatment of results. We first performed a free-floating reading to identify the main difficulties encountered by the LTCFs (Table S1). Subsequently, we explored the material to establish central themes and related subcategories. We then coded the responses in order to calculate each category's frequency and to extract parts of the related text, thus creating a Venn diagram (Figure 1). 
medRxiv preprint doi: https://doi.org/10.1101/2021.06.12.21258774; this version posted June 14, 2021. The copyright holder for this preprint (which was not certified by peer review) is the author/funder, who has granted medRxiv a license to display the preprint in perpetuity.

It is made available under a CC-BY-NC-ND 4.0 International license .

\section{RESULTS}

We received 374 replies during the 12-week investigation period. Five LTCF managers who answered the questionnaire twice had their oldest and less complete responses excluded; one reply from a non-Brazilian LTCF was also excluded. Six managers did not provide data on the number of residents, so their responses were not included. This resulted in 362 LTCFs included in the analysis.

Altogether the 362 LTCFs served a population of 11]903 older adults. The Southeast region of Brazil had the largest proportion of included facilities (53.8\%), most of which were for-profit LTCFs (39.7\%) and not-for-profit LTCFs receiving government/nongovernment funds (37.5\%). Table 1 shows the characteristics of the LTCFs included in the study, divided according to facility size.

Regarding funding, 166 LTCF managers (45.1\%) reported that they had not received any funding or external financial support to prepare themselves to deal with the pandemic, including training, purchasing of PPE, and infrastructure adjustments for respiratory isolation of suspected cases.

Two hundred and thirty-five managers (64.9\%; 74 missing data) answered that their facilities already had the necessary infrastructure to accommodate residents with suspected COVID-19, including rooms with a private bathroom and sufficient space for employees and residents to carry out preventive, hygiene, and protection practices.

Access to laboratory tests for influenza and coronavirus was low: $23.5 \%(n=85)$ had access to neither, and $17.4 \%(n=63)$ had access only to SARS-CoV-2 rapid test kits.

Table 2 summarizes adherence to WHO IPC guidance for LTCFs in the context of COVID-19. Of 362 LTCFs, 308 (85.1\%) adhered to 14 or more WHO IPC guidance recommendations; 3 LTCFs were classified as poorly adherent, and 35 (9.7\%) had missing data. Regarding LTCF size, we found a lower adherence to screening visitors for 
medRxiv preprint doi: https://doi.org/10.1101/2021.06.12.21258774; this version posted June 14, 2021. The copyright holder for this preprint (which was not certified by peer review) is the author/funder, who has granted medRxiv a license to display the preprint in perpetuity.

It is made available under a CC-BY-NC-ND 4.0 International license .

COVID-19 signs and symptoms $(p=0.037)$ and to isolating patients until they have 2 negative laboratory tests for COVID-19 $(p=0.032)$ in larger facilities than in medium and small facilities. No significant differences were found in other recommendations between small, medium, and large LTCFs.

Table 3 describes the issues that could influence preparedness and adherence to additional technical support recommendations to deal with the COVID-19 pandemic in LTCFs, involving questions not included in the global adherence score. The most common issue was lack of external support ( $74.3 \%$ did not receive support to plan and execute training and contingency plans), followed by difficulty in purchasing PPE for residents and employees (47.0\%) and managing deaths within the facility (46.1\%). The creation of a multidisciplinary planning committee specifically to deal with COVID-19 issues was less common in small LTCFs (49.4\%) than in medium (65.0\%) and large (75.8\%) facilities $(p=0.034)$.

The analysis of managers' responses to the open-ended question showed that most LTCFs (98\%) were having difficulty in tackling the COVID-19 pandemic. According to the managers, the most affected areas were those related to keeping a sufficient stock of materials (42\%) (e.g., PPE, hygiene and cleaning supplies, and COVID-19 tests), financial distress (39\%) (e.g., extra expenses with materials, additional costs with staff, and fundraising issues), and managing the workforce (24\%) (e.g., absence and replacement, awareness and protocol compliance, qualification and training, and emotional distress). In $14 \%$ of LTCFs, managers reported problems related to infrastructure (e.g., adjustments for isolation of suspected/confirmed cases and enough space to ensure physical distancing) and to residents (e.g., awareness and protocol compliance, emotional distress, compliance with social distancing, management of dementia, restriction of group activities and visitors, and lack of family contact). Detailed results are available as Supplementary file 3.

Figure 1 illustrates the overlap of issues faced by LTCFs, according to their managers. The main overlap was detected between financial and materials issues (8.2\%), followed by financial vs workforce $(2.4 \%)$ and financial vs materials vs workforce 
medRxiv preprint doi: https://doi.org/10.1101/2021.06.12.21258774; this version posted June 14, 2021. The copyright holder for this preprint (which was not certified by peer review) is the author/funder, who has granted medRxiv a license to display the preprint in perpetuity.

It is made available under a CC-BY-NC-ND 4.0 International license .

(2.4\%). A $2.2 \%$ of overlap was also observed for financial vs infrastructure, materials vs workforce, and workforce vs residents. The remaining overlaps of issues faced by LTCFs were present in less than $2.0 \%$ of responses.

\section{DISCUSSION}

In this cross-sectional study, most Brazilian LTCFs (85.1\%) reported high adherence to WHO IPC guidance to mitigate COVID-19, albeit 98\% reported having difficulties with shortage of supplies, PPE, and materials, workforce management, and financial problems.

Although previous evidence clearly suggests that LTCF size is associated with an increased risk of outbreaks and deaths, and possibly with difficulty adhering to IPC measures, ${ }^{1,3}$ we found a high overall adherence rate regardless of LTCF size. The global adherence score was slightly lower in larger LTCFs for 'screening external visitors' and 'isolating infected residents'. Adherence to the recommendation of establishing multidisciplinary committees to combat COVID-19 decreased with decreasing LTCF size.

Although the size of facilities was not assessed in a recent systematic review on the epidemiology and clinical features of COVID-19 outbreaks in aged care facilities, ${ }^{20}$ larger facilities had been previously found to be correlated with the spread of infection. ${ }^{21,22}$ However, increasing testing capacity and updating surveillance protocols accordingly could facilitate earlier detection of emerging outbreaks and help these facilities manage the supply of care workers and quality of nursing homes, especially their response to infectious diseases. ${ }^{21}$

Many LTCFs have perceived a considerably high workload during the COVID-19 pandemic. Tasks and activities that require direct involvement of the workforce, such as caring for infected residents (particularly those with functional impairment and cognitive decline) and screening external visitors, would be expected to have the most 
medRxiv preprint doi: https://doi.org/10.1101/2021.06.12.21258774; this version posted June 14, 2021. The copyright holder for this preprint (which was not certified by peer review) is the author/funder, who has granted medRxiv a license to display the preprint in perpetuity.

It is made available under a CC-BY-NC-ND 4.0 International license .

significant impact on facilities with the highest number of residents. This impact, however, was not sufficient to reduce adherence to IPC guidance significantly.

In the United States, COVID-19 mortality was found to be higher in significantly more crowded facilities (9.7\%) than in less crowded ones (4.5\%), regardless of facility size. ${ }^{23}$ The size of LTCFs was strongly associated with COVID-19 outbreaks (odds ratio per 20bed increase 3.35 , 95\% confidence interval 1.99-5.63). ${ }^{24}$ Meanwhile, in the UK, the likelihood of spread of COVID-19 was higher for larger LTCFs (>20 beds) and when workers and facilities did not adhere to IPC measures to mitigate infection risk. ${ }^{25}$ Preparedness and adherence to recommendations by LTCFs, however, have been poorly described in low- and middle income countries (LMICS).

Prevention is a critical component of infection control, particularly during emerging outbreaks. The long-term care sector in LMICs remains mostly underdeveloped, and specific strategies must be considered and suited to promote and successfully implement IPC protocols and guidelines. In a study of high-risk populations in a highincome country, IPC implementation significantly differed between higher- and lower-prevalence groups in the social distancing and PPE categories. ${ }^{23}$

Some factors can potentially influence adherence to IPC guidance by acting as facilitators or barriers to its implementation. The community prevalence of COVID-19, the availability of screening tests, and the rate of infection among workers (including staff turnover and retention) may influence adherence to some of the IPC recommendations. Other factors that may affect adherence include the facility's occupancy rate, inadequate staff IPC measures to minimize staff-to-staff transmission, delayed recognition of cases in residents because of a low index of suspicion, and residents at risk for severe morbidity and death sharing a location. ${ }^{25}$

Despite the lack of official data, COVID-19 mortality in Brazilian LTCFs is lower than in other countries. ${ }^{6}$ Although the early suspension of visits to LTCFs has been hypothesized to influence these rates, there is no robust evidence to support this statement at the moment. The adoption of good practices to mitigate the impact of 
medRxiv preprint doi: https://doi.org/10.1101/2021.06.12.21258774; this version posted June 14, 2021. The copyright holder for this preprint (which was not certified by peer review) is the author/funder, who has granted medRxiv a license to display the preprint in perpetuity.

It is made available under a CC-BY-NC-ND 4.0 International license .

COVID-19, such as training targeting the workforce, use of PPE, and adherence to the IPC guidance, may have influenced the results; however, these results still need confirmation by longitudinal studies. Previous studies involving 23?896 Brazilian respondents (mean age, 47.4years) have identified a satisfactory level of adherence to national COVID-19 prevention guidelines. Younger people, males, persons living in rural areas/villages or in densely populated or low-income neighborhoods, students, and workers often engage in less preventive behavior. ${ }^{26}$

This study has limitations inherent in the cross-sectional design adopted and the potential for recall bias. Likewise, potential selection bias may have favored LTCFs with access to the internet and those with more complete teams, including workers dedicated to administrative tasks. The instrument used for data collection was tested in a pilot study, ${ }^{18}$ but it is not a validated instrument. Also, there are no established cutoff points to classify facilities by size, which may have influenced the findings. Nevertheless, all definitions adopted for the purpose of this study were defined a priori, and a large and nationally representative number of LTCFs was included.

COVID-19 has been a pandemic, or a syndemic, ${ }^{27}$ of inequalities. Countries with successful responses, for instance, developed partnerships on multiple levels across government sectors, had timely triage and referral of suspected COVID-19 cases, and provided designated isolation facilities. ${ }^{28}$ The drama observed at the beginning of the pandemic, when COVID-19 deaths among LTCF residents were brutally high in some countries, was partly due to the lack of official guidelines and regulations for natural disasters and pandemics worldwide. ${ }^{29}$ Researchers found that only $57 \%$ of 182 countries could perform crucial activities to prevent, detect, and respond to an outbreak in the context of COVID-19. ${ }^{30}$ As previously stated, context matters. ${ }^{27}$

Coronavirus outbreaks will probably continue to occur worldwide for the following years, similar to other respiratory viruses. ${ }^{23,27}$ The effects of vaccination and immunity rates remain largely unknown, and they may be lower in LTCF residents due to immunosenescence. ${ }^{28}$ 
medRxiv preprint doi: https://doi.org/10.1101/2021.06.12.21258774; this version posted June 14, 2021. The copyright holder for this preprint (which was not certified by peer review) is the author/funder, who has granted medRxiv a license to display the preprint in perpetuity. It is made available under a CC-BY-NC-ND 4.0 International license.

In conclusion, based on adherence to WHO IPC guidance, preparedness for mitigating COVID-19 in Brazilian LTCFs in this study was considered excellent for most of the proposed recommendations, regardless of LTCF size. Difficulties and problems with infrastructure and/or resident care were much less commonly reported than those related to maintenance of a sufficient stock of materials, workforce management, and financial distress. 
medRxiv preprint doi: https://doi.org/10.1101/2021.06.12.21258774; this version posted June 14, 2021. The copyright holder for this preprint (which was not certified by peer review) is the author/funder, who has granted medRxiv a license to display the preprint in perpetuity.

It is made available under a CC-BY-NC-ND 4.0 International license.

\section{Acknowledgments}

We thank researcher Helena Akemi Wada Watanabe, the 'Frente Nacional de Fortalecimento às ILPIs,' and the group of professionals and researchers from the ilpi.me website for their support in carrying out this study.

\section{Disclosure statement}

The authors declare no conflicts of interest. 
medRxiv preprint doi: https://doi.org/10.1101/2021.06.12.21258774; this version posted June 14, 2021. The copyright holder for this preprint (which was not certified by peer review) is the author/funder, who has granted medRxiv a license to display the preprint in perpetuity. It is made available under a CC-BY-NC-ND 4.0 International license .

References

1. Abrams HR, Loomer L, Gandhi A, Grabowski DC. Characteristics of U.S. Nursing Homes with COVID-19 Cases. Journal of the American Geriatrics Society. 2020;68(8):1653-6.

2. Comas-Herrera A, Zalakaín J, Lemmon E, Litwin C, Hsu AT, Schmidt AE, et al. Mortality associated with COVID-19 in care homes: international evidence [Internet]. 2020. 2020. Available from: https://ltccovid.org/wpcontent/uploads/2020/10/Mortality-associated-with-COVID-among-peopleliving-in-care-homes-14-October-2020-3.pdf

3. Gorges RJ, Konetzka RT. Staffing Levels and COVID-19 Cases and Outbreaks in U.S. Nursing Homes. J Am Geriatr Soc. 2020 Aug 8;

4. Wachholz PA, Moreira VG, Oliveira D, Watanabe HAW, Boas PJFV. Estimates of infection and mortality from COVID-19 in care homes for older people in Brazil. Geriatr Gerontol Aging. 2020;14(4):290-3.

5. Sepulveda ER, Stall NM, Sinha SK. A Comparison of COVID-19 Mortality Rates Among Long-Term Care Residents in 12 OECD Countries. Journal of the American Medical Directors Association. 2020 Nov;21(11):1572-1574.e3.

6. Hanratty B, Burton JK, Goodman C, Gordon AL, Spilsbury K. Covid-19 and lack of linked datasets for care homes. BMJ [Internet]. 2020 Jun 24 [cited 2020 Oct 21];369. Available from: https://www.bmj.com/content/369/bmj.m2463

7. Fisman DN, Bogoch I, Lapointe-Shaw L, McCready J, Tuite AR. Risk Factors Associated With Mortality Among Residents With Coronavirus Disease 2019 (COVID-19) in Long-term Care Facilities in Ontario, Canada. JAMA Netw Open. $2020 \mathrm{Jul}$ 22;3(7):e2015957.

8. World Health Organization, Regional Office for South-East Asia. Infection prevention and control guidance for long-term care facilities in the context of COVID-19: interim guidance, 21 March 2020 [Internet]. Infection prevention and control guidance for long-term care facilities in the context of COVID-19: interim guidance, 21 March 2020. 2020 [cited 2020 Oct 28]. Available from: https://apps.who.int/iris/handle/10665/331508

9. CDC. Coronavirus Disease 2019 (COVID-19) [Internet]. Centers for Disease Control and Prevention. 2020 [cited 2020 Oct 28]. Available from:

https://www.cdc.gov/coronavirus/2019-ncov/hcp/long-term-care.html

10. British Geriatric Society. Managing the COVID-19 pandemic in care homes [Internet]. BGS; 2020 [cited 2020 Jul 21]. Report No.: v3. Available from: www.bgs.org.uk/COVID-19

11. Comas-Herrera A, Fernández J-L. Summary of international policy measures to limit impact of COVID19 on people who rely on the Long-Term Care sector 
medRxiv preprint doi: https://doi.org/10.1101/2021.06.12.21258774; this version posted June 14, 2021. The copyright holder for this preprint (which was not certified by peer review) is the author/funder, who has granted medRxiv a license to display the preprint in perpetuity. It is made available under a CC-BY-NC-ND 4.0 International license .

[Internet]. London, UK: International Long-Term Care Policy Network; 2020 [cited 2020 Oct 28]. Available from: https://ltccovid.org/

12. Quigley DD, Dick A, Agarwal M, Jones KM, Mody L, Stone PW. COVID-19 Preparedness in Nursing Homes in the Midst of the Pandemic. J Am Geriatr Soc. 2020 Jun;68(6):1164-6.

13. Damschroder LJ, Aron DC, Keith RE, Kirsh SR, Alexander JA, Lowery JC. Fostering implementation of health services research findings into practice: a consolidated framework for advancing implementation science. Implementation Sci. 2009 Dec;4(1):50.

14. Babar Z, Austin Z. Encyclopedia of pharmacy practice and clinical pharmacy volume 1, volume 1,. 2019.

15. Helfrich CD, Li Y-F, Sharp ND, Sales AE. Organizational readiness to change assessment (ORCA): Development of an instrument based on the Promoting Action on Research in Health Services (PARIHS) framework. Implementation Sci. 2009 Dec;4(1):38.

16. Zúñiga $\mathrm{F}$, Chu CH, Boscart V, Fagertun A, Gea-Sánchez M, Meyer J, et al. Recommended Common Data Elements for International Research in Long-Term Care Homes: Exploring the Workforce and Staffing Concepts of Staff Retention and Turnover. Gerontol Geriatr Med. 2019 Dec;5:2333721419844344.

17. Lepore M, Scales K, Anderson RA, Porter K, Thach T, McConnell E, et al. Persondirected care planning in nursing homes: A scoping review. Int J Older People Nurs. 2018 Dec;13(4):e12212.

18. Wachholz PA, Jacinto AF, Melo RC de, Dinamarca-Montecinos JL, Villas Boas PJF. COVID-19: challenges in long-term care facilities for older adults in Hispanic American countries. Geriatr, Gerontol Aging (Impr). 2020;14(4):259-66.

19. Bardin L. L'analyse de contenu. Paris: Presses univ. de France; 2005.

20. Hashan MR, Smoll N, King C, Ockenden-Muldoon H, Walker J, Wattiaux A, et al. Epidemiology and clinical features of COVID-19 outbreaks in aged care facilities: A systematic review and meta-analysis. EClinicalMedicine. 2021 Mar;33:100771.

21. Bagchi S, Mak J, Li Q, Sheriff E, Mungai E, Anttila A, et al. Rates of COVID-19 Among Residents and Staff Members in Nursing Homes - United States, May 25November 22, 2020. MMWR Morb Mortal Wkly Rep. 2021 Jan 15;70(2):52-5.

22. Abe K, Kawachi I. Deaths in Nursing Homes During the COVID-19 PandemicLessons from Japan. JAMA Health Forum. $2021 \mathrm{Feb}$ 12;2(2):e210054.

23. Telford CT, Bystrom C, Fox T, Holland DP, Wiggins-Benn S, Mandani A, et al. COVID-19 Infection Prevention and Control Adherence in Long-Term Care Facilities, Atlanta, Georgia. J Am Geriatr Soc. 2021 Mar;69(3):581-6. 
medRxiv preprint doi: https://doi.org/10.1101/2021.06.12.21258774; this version posted June 14, 2021. The copyright holder for this preprint (which was not certified by peer review) is the author/funder, who has granted medRxiv a license to display the preprint in perpetuity.

It is made available under a CC-BY-NC-ND 4.0 International license .

24. Burton JK, Bayne G, Evans C, Garbe F, Gorman D, Honhold N, et al. Evolution and effects of COVID-19 outbreaks in care homes: a population analysis in 189 care homes in one geographical region of the UK. The Lancet Healthy Longevity. 2020 Oct;1(1):e21-31.

25. European Centre for Disease Prevention and Control. Increase in fatal cases of COVID-19 among long-term care facility residents in the EU/EEA and the UK. 2020 Nov 19;42.

26. Faria de Moura Villela E, López RVM, Sato APS, de Oliveira FM, Waldman EA, Van den Bergh R, et al. COVID-19 outbreak in Brazil: adherence to national preventive measures and impact on people's lives, an online survey. BMC Public Health. 2021 Dec;21(1):152.

27. Mendenhall E. The COVID-19 syndemic is not global: context matters. The Lancet. 2020 Nov;396(10264):1731.

28. Sirleaf EJ, Clark H. Report of the Independent Panel for Pandemic Preparedness and Response: making COVID-19 the last pandemic. The Lancet. 2021 May;S0140673621010953.

29. Thompson D-C, Barbu M-G, Beiu C, Popa LG, Mihai MM, Berteanu M, et al. The Impact of COVID-19 Pandemic on Long-Term Care Facilities Worldwide: An Overview on International Issues. Baloyannis S, editor. BioMed Research International. 2020 Nov 4;2020:1-7.

30. Jacobsen KH. Will COVID-19 generate global preparedness? The Lancet. 2020 Mar;395(10229):1013-4. 
medRxiv preprint doi: https://doi.org/10.1101/2021.06.12.21258774; this version posted June 14, 2021. The copyright holder for this preprint (which was not certified by peer review) is the author/funder, who has granted medRxiv a license to display the preprint in perpetuity.

It is made available under a CC-BY-NC-ND 4.0 International license.

\section{Figure legends}

Figure 1. Venn diagram showing the overlap of issues faced by long-term care facilities. 


\section{Tables}

Table 1. Characteristics of 362 Brazilian long-term care facilities for older people, according to facility size, whose managers answered an online questionnaire to identify their preparedness for the COVID-19 pandemic. 
Table 2. Adherence to the World Health Organization infection prevention and control guidance for long-term care facilities in the context of COVID-19 in 362 Brazilian care homes. 
Table 3. Preparedness and adherence to technical support recommendations to tackle the COVID-19 pandemic in 362 Brazilian long-term care facilities. 


\section{Supporting information}

Doc S1 - COMPLETE QUESTIONNAIRE

Doc S2 - QUESTIONS INCLUDED IN THE GLOBAL SCORE FOR ADHERENCE TO WHO IPC GUIDANCE

Table S1 - "Free-floating reading" coding on the main difficulties encountered by LTCFs in coping with the COVID-19 pandemic. 
Table 1. Characteristics of 362 Brazilian long-term care facilities for older people, according to facility size, whose managers answered an online questionnaire to identify their preparedness for the COVID-19 pandemic.

\begin{tabular}{|c|c|c|c|}
\hline \multirow[b]{2}{*}{ Characteristic } & \multicolumn{3}{|c|}{ Facility size } \\
\hline & $\begin{array}{l}\text { Small facilities } \\
\quad(n=172)\end{array}$ & $\begin{array}{l}\text { Medium facilities } \\
\quad(n=157)\end{array}$ & $\begin{array}{l}\text { Large facilities } \\
\qquad(n=33)\end{array}$ \\
\hline \multicolumn{4}{|l|}{ Number of residents } \\
\hline Median (IQR) & $18(16.8-18.5)$ & $37(37.5-40.3)$ & $76(74.6-92.2)$ \\
\hline Mean (SD) & $17.7(5.7)$ & $38.9(8.8)$ & $83.4(24.8)$ \\
\hline \multicolumn{4}{|l|}{ Funding source, $n(\%)$} \\
\hline Public & $10(5.8)$ & $6(3.8)$ & $2(6.0)$ \\
\hline For-profit & $98(56.9)$ & $40(25.5)$ & $4(12.1)$ \\
\hline Not-for-profit type $1 *$ & $43(25.0)$ & $76(48.4)$ & $18(54.5)$ \\
\hline Not-for-profit type $2^{* *}$ & $21(12.2)$ & $35(22.2)$ & $9(27.3)$ \\
\hline
\end{tabular}

$\mathrm{IQR}=$ interquartile range; $\mathrm{SD}=$ standard deviation.

* Long-term care facilities that receive government/nongovernment funds;

**Long-term care facilities that work on behalf of people other than their founders or directors and can be reimbursed for the services provided (usually charity entities). 
Table 2. Adherence to the World Health Organization infection prevention and control guidance for long-term care facilities in the context of COVID-19 in 362 Brazilian care homes.

\section{RECOMMENDATION}

\begin{tabular}{|c|c|c|c|c|c|}
\hline \multirow{2}{*}{ RECOMMENDATION } & \multicolumn{5}{|c|}{$\begin{array}{c}\text { ADHERENCE } \\
n(\%)\end{array}$} \\
\hline & $\begin{array}{c}\text { TOTAL } \\
\text { (n=362) }\end{array}$ & $\begin{array}{c}\text { Small } \\
(n=172)\end{array}$ & $\begin{array}{l}\text { Medium } \\
(n=157)\end{array}$ & $\begin{array}{l}\text { Large } \\
\text { (n=33) }\end{array}$ & $p$-value \\
\hline \multicolumn{6}{|l|}{ PREVENTION } \\
\hline Provide COVID-19 IPC training to all employees & $288(79.6)$ & $132(76.7)$ & $\begin{array}{c}128 \\
(81.5)\end{array}$ & $28(84.8)$ & 0.611 \\
\hline Provide information sessions for residents & $258(71.3)$ & $121(70.3)$ & $\begin{array}{l}109 \\
(69.4)\end{array}$ & $28(84.8)$ & 0.241 \\
\hline Regularly audit IPC practices & $320(88.4)$ & $146(84.9)$ & $\begin{array}{c}145 \\
(92.4)\end{array}$ & $29(87.9)$ & 0.108 \\
\hline Post reminders, posters, flyers around the facility & 302 (83.4) & $148(86.0)$ & $\begin{array}{c}125 \\
(79.6)\end{array}$ & $29(87.9)$ & 0.423 \\
\hline Ensure physical distancing in the facility (for group activities) & $305(84.3)$ & $146(84.9)$ & $\begin{array}{c}132 \\
(84.1)\end{array}$ & $27(81.8)$ & 0.894 \\
\hline Ensure physical distancing in the facility (for meals) & $212(58.6)$ & $103(59.9)$ & $92(58.6)$ & $17(51.5)$ & 0.772 \\
\hline
\end{tabular}




\begin{tabular}{|c|c|c|c|c|c|}
\hline Require residents and employees to avoid touching & $344(95.0)$ & $163(94.8)$ & $\begin{array}{c}148 \\
(94.3)\end{array}$ & $33(100)$ & 0.539 \\
\hline \multicolumn{6}{|l|}{ RULES FOR VISITORS } \\
\hline Screen for signs and symptoms or risk for COVID-19 & $337(93.1)$ & $161(93.6)$ & $\begin{array}{c}148 \\
(94.3)\end{array}$ & $28(84.8)$ & 0.037 \\
\hline \multicolumn{6}{|l|}{ PROSPECTIVE SURVEILLANCE FOR COVID-19 AMONG RESIDENTS } \\
\hline Assess the health status of any new residents on admission & $344(95.0)$ & $164(95.3)$ & $\begin{array}{c}148 \\
(94.3)\end{array}$ & $32(97.0)$ & 0.700 \\
\hline Assess each resident twice daily for signs & $336(92.8)$ & $160(93.0)$ & $\begin{array}{c}146 \\
(93.0)\end{array}$ & 30 (90.9) & 0.206 \\
\hline Immediately report residents with fever or respiratory symptoms & 358 (98.9) & $168(97.7)$ & $157(100)$ & $33(100)$ & 0.346 \\
\hline \multicolumn{6}{|l|}{ PROSPECTIVE SURVEILLANCE AMONG EMPLOYEES } \\
\hline Conduct prospective surveillance for employees (in case of symptoms) & $355(98.1)$ & $168(97.7)$ & $\begin{array}{c}156 \\
(99.4)\end{array}$ & $31(93.9)$ & 0.223 \\
\hline Follow up employees with unexplained absences & $328(90.6)$ & $157(91.3)$ & $\begin{array}{c}142 \\
(90.4)\end{array}$ & $29(87.9)$ & 0.568 \\
\hline Undertake temperature checks for all employees at the facility entrance & $275(76.0)$ & $128(74.4)$ & $\begin{array}{c}122 \\
(77.7)\end{array}$ & $25(75.8)$ & 0.777 \\
\hline \multicolumn{6}{|l|}{ PROVISION AND AVAILABILITY OF PPE AND CLEANING SUPPLIES } \\
\hline Employees should use contact and droplet precautions & $327(90.3)$ & $155(90.1)$ & 143 & $29(87.9)$ & 0.792 \\
\hline
\end{tabular}


PPE use following recommended procedures to avoid contamination

\section{SOURCE CONTROL}

Notify local authorities about any suspected case and isolate residents with onset of respiratory symptoms

\section{RESTRICTION OF MOVEMENT AND TRANSPORT}

Confirmed patients should not leave their rooms while ill

Isolate COVID-19 patients until they have 2 negative laboratory tests

$I P C=$ infection prevention and control; $P P E=$ personal protective equipment.

$\begin{array}{lcccc}345(95.3) & 162(94.2) & \begin{array}{c}152 \\ (96.8)\end{array} & 31(93.9) & 0.386 \\ 228(63.0) & 101(59.7) & \begin{array}{c}100 \\ (43.9)\end{array} & 27(81.8) & 0.190 \\ 338(93.4) & 162(94.2) & \begin{array}{c}147 \\ (93.6)\end{array} & 29(87.9) & 0.057 \\ 329(90.9) & 158(91.9) & \begin{array}{c}142 \\ (90.4)\end{array} & 29(87.9) & 0.032\end{array}$


Table 3. Preparedness and adherence to technical support recommendations to tackle the COVID-19 pandemic in 362 Brazilian long-term care facilities.

\section{RECOMMENDATION}

CONTINGENCY PLAN
Managers have discussed, analyzed, or considered developing a contingency plan
to identify the minimum number of employees needed to operate safely.
Managers have effectively implemented a contingency plan to identify the
minimum number of employees needed to operate safely and on how to hire or
recruit them.

A multidisciplinary planning committee has been created specifically to decide and discuss the planning of actions to prevent and combat COVID-19.

\section{PERSONAL PROTECTIVE EQUIPMENT (PPE)}

Residents and employees have access to comfortable and sufficient PPE.

The facility is having difficulty in purchasing or stocking cleaning supplies and PPE for residents and employees.

\begin{tabular}{|c|c|c|c|c|}
\hline \multicolumn{5}{|c|}{$\begin{array}{c}\text { ADHERENCE } \\
n(\%)\end{array}$} \\
\hline $\begin{array}{c}\text { TOTAL } \\
(n=362)\end{array}$ & $\begin{array}{c}\text { Small } \\
(n=172)\end{array}$ & $\begin{array}{c}\text { Medium } \\
(n=157)\end{array}$ & $\begin{array}{l}\text { Large } \\
(n=33)\end{array}$ & $p$-value \\
\hline $276(72.7)$ & $128(74.4)$ & $124(79.0)$ & $24(72.7)$ & 0.838 \\
\hline $241(66.6)$ & $110(64.0)$ & $109(69.4)$ & $22(66.7)$ & 0.304 \\
\hline $212(58.6)$ & $85(49.4)$ & $102(65.0)$ & $25(75.8)$ & 0.034 \\
\hline $323(89.2)$ & $156(90.7)$ & $137(87.3)$ & $30(90.9)$ & 0.716 \\
\hline $192(53.0)$ & 89 (51.7) & $89(56.7)$ & $14(42.2)$ & 0.499 \\
\hline
\end{tabular}




\section{MANAGEMENT OF SUSPECTED/CONFIRMED CASES AND DEATHS}

The facility has established care flows with local health authorities or referral units to transfer suspected cases.

Managers have developed a contingency plan to deal with deaths within the

facility.

\section{EXTERNAL SUPPORT}

The facility has received funding or external support to plan and execute the training and contingency plans needed to deal with the COVID-19 pandemic.

$\begin{array}{lllll}228(63.0) & 101(58.7) & 100(63.7) & 27(81.8) & 0.199 \\ 195(53.9) & 80(46.5) & 95(60.5) & 20(60.6) & 0.249 \\ 93(25.7) & 33(19.2) & 48(30.6) & 12(36.4) & 0.169\end{array}$




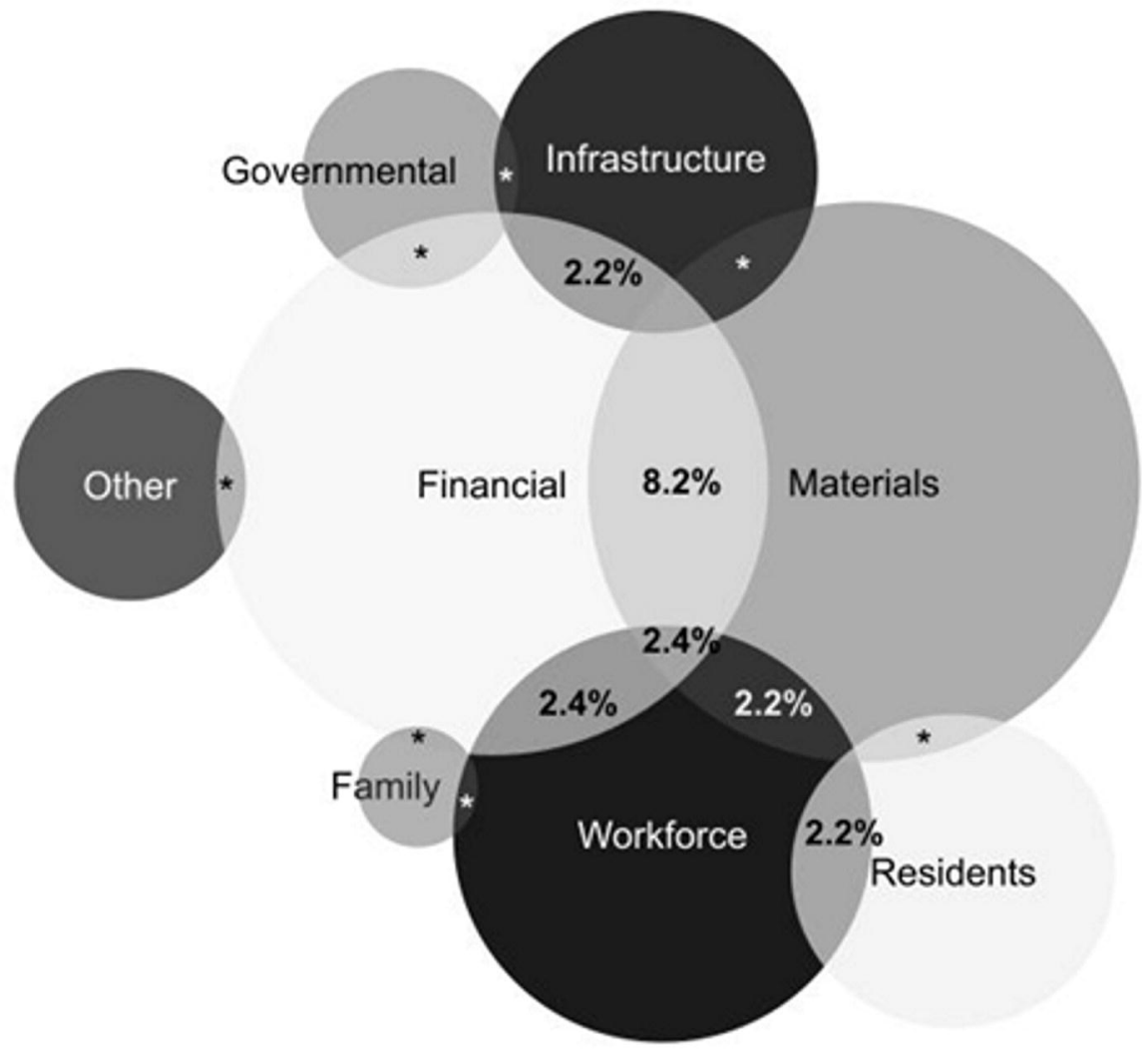

